See discussions, stats, and author profiles for this publication at: https://www.researchgate.net/publication/271868198

\title{
Preparation and some physicochemical properties of benzylammonium sulfates
}

Article in Russian Journal of General Chemistry · April 2014

DOI: 10.1134/\$1070363214040069

CITATIONS

READS

20

7 authors, including:

Ruslan Khoma

Odessa National University

47 PUBLICATIONS 89 CITATIONS

SEE PROFILE

Vyacheslav N Baumer

National Academy of Sciences of Ukraine

308 PUBLICATIONS 1,321 CITATIONS

SEE PROFILE

Some of the authors of this publication are also working on these related projects:

Proton Transfer in 3-Hydroxychromones View project 


\title{
Preparation and Some Physicochemical Properties of Benzylammonium Sulfates
}

\author{
R. E. Khoma ${ }^{a, b}$, A. A. Ennan ${ }^{a}$, V. O. Gelmboldt ${ }^{c}$, O. V. Shishkin ${ }^{d, e}$, \\ V. N. Baumer ${ }^{d, e}$, A. V. Mazepa ${ }^{f}$, and Yu. E. Brusilovskiif \\ ${ }^{a}$ Physicochemical Institute of Environment and Human Protection, \\ ul. Preobrazhenskaya 3, Odessa, 65082 Ukraine \\ e-mail:rek@onu.edu.ua,r_khoma@farlep.net \\ ${ }^{b}$ Mechnikov Odessa National University, Odessa, Ukraine \\ ${ }^{c}$ Odessa National Medical University, Odessa, Ukraine \\ ${ }^{d}$ Institute of Single Crystals, National Academy of Sciences of Ukraine, Kharkov, Ukraine \\ ${ }^{e}$ Karazin Kharkov National University, Kharkov, Ukraine \\ ${ }^{f}$ Bogatskii Physicochemical Institute, National Academy of Sciences of Ukraine, Odessa, Ukraine
}

Received June 17, 2013

\begin{abstract}
New method of preparation of multisubstituted benzylammonium cations via interaction in the $\mathrm{SO}_{2}-\mathrm{L}-\mathrm{H}_{2} \mathrm{O}$ systems ( $\mathrm{L}$ is benzylamine, $\alpha$-phenylethylamine, $N, N$-dimethylbenzylamine, or dibenzylamine) has been developed. The products have been studied by X-ray diffraction, IR, Raman spectroscopy, and mass spectrometry.
\end{abstract}

Keywords: benzylamine, benzylammonium sulfate, X-ray diffraction, IR, Raman spectra

DOI: $10.1134 / \mathrm{S} 1070363214040069$

Benzylamine and its derivatives are known to form salts with inorganic [1-7] as well as organic [8-10] acids. Of these salts, nitrate [1], sulfate [2], dihydrophosphate [3], and hydroarsenate monohydrate [4] of benzylammonium; sulfate and hydrophosphate of $(S)$ $\alpha$-phenylethylammonium [5]; trifluoroacetate of $(R)-\alpha-$ phenylethylammonium [8]; as well as saturated [9] and $\alpha, \beta$-unsaturated [10] carboxylates of $( \pm)$ - $\alpha$-phenylethylammonium and its phenyl derivatives have been described and characterized. The interest to the abovementioned compounds is due to their possible applications. The soluble benzylammonium salts have attracted attention as drugs of enhanced bioavailability [11]; in particular, dibenzylamine forms a watersoluble antibiotic salt with penicillin [12]. Sulfate and hydrophosphate of $(S)$-1-phenylethylammonium have been studied as components of new dielectric nonlinear optical materials [5]. Salts of $N$-alkyldimethylbenzylammonium with inorganic anions have been used as antiseptics and disinfectants [13].

In this work, we describe the preparation, structure, spectral features, and thermal stability of sulfates I-IV obtained from benzylamine, $\alpha$-phenylethylamine, $N, N$ dimethylbenzylamine, and dibenzylamine, respectively.

Under conditions of mass spectra detection, compounds I, III, and IV underwent a so-called benzyl cleavage [14]; the $\left[\mathrm{C}_{7} \mathrm{H}_{7}\right]^{+}$peak was found in the spectra, being the most intense in the spectrum of compound IV.

The structure of compound II as determined by $\mathrm{X}$-ray diffraction analysis was similar to that of benzylammonium described in [2].

The $\mathrm{SO}_{4}^{2-}$ anion is located in the particular position at the twofold axis, one $\mathrm{C}_{8} \mathrm{H}_{12} \mathrm{~N}^{+}$cation and half of sulfate ion are located in the independent part of the cell (Fig. 1). The bond lengths and bond angles between the nonhydrogen atoms are collected in Tables 1 and 2. At packing in the crystal a system of hydrogen bonds is formed, their parameters are listed in Table 3. The hydrogen bonds are formed between ammonium group of the cation and oxygen atoms of sulfate ions; the bonds are located in the vicinity of the $z=1 / 2$ plane, forming a layer in the $0<z<1$ region. 


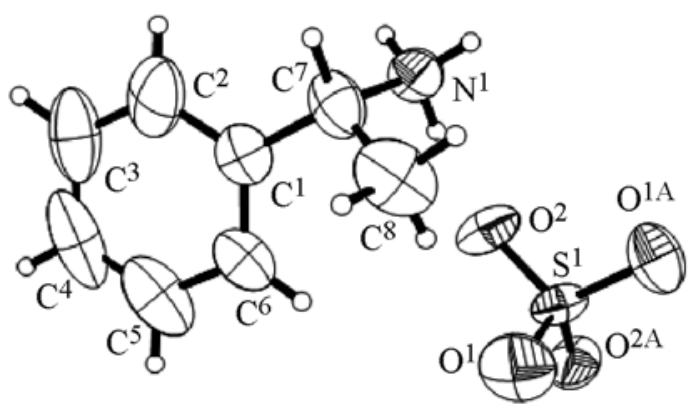

Fig. 1. General view of molecule of compounds II (thermal ellipsoids of probability level $50 \%$ ). Symmetrically equivalent atoms are denoted as $\mathrm{A}$.

In between these layers no hydrogen bonds are found, as shown in Fig. 2. Due to this peculiar structural feature, crystals of II are layered, are of poor quality and tend to twinning.

Selected parameters of IR spectra of the initial amines and compounds $\mathbf{I}-\mathbf{I V}$ are shown in Table 4.

Assignment of vibration frequencies of $\mathrm{SO}_{4}^{2-}$ in IR spectrum of I was performed by comparison with IR spectrum of initial benzylamine and the corresponding Raman spectra taking into account the data reported in [15].

Proper assignment of the $v_{\text {as }}$ band of $\mathrm{SO}_{4}^{2-}$ in IR spectrum of I was complicated by the overlapping with vibration bands of benzylammonium cation at $1100 \mathrm{~cm}^{-1}$. However, the corresponding Raman vibrations of benzylammonium were relatively inactive, thus allowing to extract three split components of thrice degenerate asymmetric vibrations $v_{3}\left(\mathrm{~F}_{2}\right)$ as bands of medium $\left(1165 \mathrm{~cm}^{-1}\right)$ and high $\left(1093\right.$ and $\left.1033 \mathrm{~cm}^{-1}\right)$ intensity. Hence, complication of IR spectrum of sulfate I as compared with that of initial amine (the appearance of a complex intense band with maximum

Table 1. Bond lengths in the molecule of sulfate II

\begin{tabular}{c|c||c|c||c|c}
\hline Bond & $d, \AA$ & Bond & $d, \AA$ & Bond & $d, \AA$ \\
\hline $\mathrm{S}^{1}-\mathrm{O}^{2}$ & $1.458(5)$ & $\mathrm{C}^{1}-\mathrm{C}^{2}$ & $1.425(11)$ & $\mathrm{C}^{4}-\mathrm{C}^{5}$ & $1.366(17)$ \\
$\mathrm{S}^{1}-\mathrm{O}^{1}$ & $1.473(5)$ & $\mathrm{C}^{1}-\mathrm{C}^{7}$ & $1.505(10)$ & $\mathrm{C}^{5}-\mathrm{C}^{6}$ & $1.370(11)$ \\
$\mathrm{N}^{1}-\mathrm{C}^{7}$ & $1.525(8)$ & $\mathrm{C}^{2}-\mathrm{C}^{3}$ & $1.305(13)$ & $\mathrm{C}^{7}-\mathrm{C}^{8}$ & $1.523(12)$ \\
$\mathrm{C}^{1}-\mathrm{C}^{6}$ & $1.410(11)$ & $\mathrm{C}^{3}-\mathrm{C}^{4}$ & $1.429(15)$ & & \\
\hline
\end{tabular}

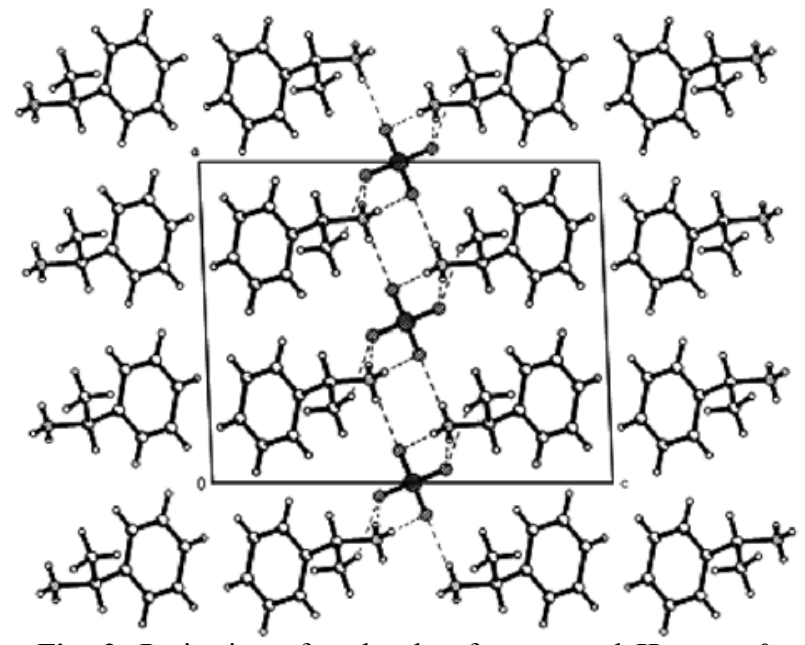

Fig. 2. Projection of molecule of compound II onto $x 0 z$ plane. Hydrogen bonds are denoted with dashed lines.

at $\sim 1118 \mathrm{~cm}^{-1}$ and a shoulder at $1160 \mathrm{~cm}^{-1}$ instead of a singlet band at $1145 \mathrm{~cm}^{-1}$ and a shoulder at $1085 \mathrm{~cm}^{-1}$ as well as enhancement of the band at $1030 \mathrm{~cm}^{-1}$ ) resulted from overlap of the cation bands with $v_{\text {as }}\left(\mathrm{SO}_{4}^{2-}\right)$.

In Raman spectrum of compound $\mathbf{I}$, the intense band at $966 \mathrm{~cm}^{-1}$ was observed, absent in the spectrum of benzylamine; the band could be assigned to the fullsymmetrical vibrations $v_{\mathrm{s}}\left(\mathrm{SO}_{4}^{2-}\right)$. As was discussed in [15], the decrease in the symmetry of sulfate anion led to the appearance of weak full-symmetrical vibration band $v_{1}\left(A_{1}\right)$ in IR spectrum, its frequency being practically equal to that of the Raman band. Therefore, the newly appeared weak band at $961 \mathrm{~cm}^{-1}$ in IR spectrum of sulfate $\mathbf{I}$ was assigned to $v_{\mathrm{s}}\left(\mathrm{SO}_{4}^{2-}\right)\left(\mathrm{A}_{1}\right)$.

Table 2. Bond angles in the molecule of sulfate $\mathbf{I I}^{\mathrm{a}}$

\begin{tabular}{l|l|l|l}
\hline Angle & $\omega$, deg & Angle & $\omega$, deg \\
\hline $\mathrm{O}^{2} \mathrm{~S}^{1} \mathrm{O}^{2 \# 1}$ & $107.5(4)$ & $\mathrm{C}^{2} \mathrm{C}^{3} \mathrm{C}^{4}$ & $117.4(10)$ \\
$\mathrm{O}^{2} \mathrm{~S}^{1} \mathrm{O}^{1}$ & $109.0(3)$ & $\mathrm{C}^{5} \mathrm{C}^{4} \mathrm{C}^{3}$ & $118.5(10)$ \\
$\mathrm{O}^{2} \mathrm{~S}^{1} \mathrm{O}^{1 \# 1}$ & $110.0(3)$ & $\mathrm{C}^{4} \mathrm{C}^{5} \mathrm{C}^{6}$ & $124.5(11)$ \\
$\mathrm{O}^{1} \mathrm{~S}^{1} \mathrm{O}^{1 \# 1}$ & $111.1(5)$ & $\mathrm{C}^{5} \mathrm{C}^{6} \mathrm{C}^{1}$ & $116.7(9)$ \\
$\mathrm{C}^{6} \mathrm{C}^{1} \mathrm{C}^{2}$ & $117.5(8)$ & $\mathrm{C}^{1} \mathrm{C}^{7} \mathrm{C}^{8}$ & $114.3(7)$ \\
$\mathrm{C}^{6} \mathrm{C}^{1} \mathrm{C}^{7}$ & $120.6(7)$ & $\mathrm{C}^{1} \mathrm{C}^{7} \mathrm{~N}^{1}$ & $109.8(6)$ \\
$\mathrm{C}^{2} \mathrm{C}^{1} \mathrm{C}^{7}$ & $121.9(8)$ & $\mathrm{C}^{8} \mathrm{C}^{7} \mathrm{~N}^{1}$ & $108.2(6)$ \\
$\mathrm{C}^{3} \mathrm{C}^{2} \mathrm{C}^{1}$ & $124.8(10)$ & \\
\hline
\end{tabular}


Table 3. Parameters of hydrogen bonds D-H $\cdots \mathrm{A}$ in the molecule of sulfate II

\begin{tabular}{c|c|c|c|c|c}
\hline \multirow{2}{*}{$\begin{array}{c}\text { Bond } \\
\mathrm{D}-\mathrm{H} \cdots \mathrm{A}\end{array}$} & \multicolumn{3}{|c|}{ Distance, $\AA$} & $\begin{array}{c}\text { DHA angle, } \\
\operatorname{deg}\end{array}$ & Atom coordinates \\
\cline { 2 - 5 } & $d(\mathrm{D}-\mathrm{H})$ & $d(\mathrm{H} \cdots \mathrm{A})$ & $d(\mathrm{D} \cdots \mathrm{A})$ & 169.9 & $-x+3 / 2, y+1 / 2,-z+1$ \\
\hline $\mathrm{N}^{1}-\mathrm{H}^{1 \mathrm{~A}} \cdots \mathrm{O}^{2}$ & 0.89 & 1.92 & $2.805(8)$ & & \\
& & 1.90 & $2.786(6)$ & 171.6 & $x-1 / 2, y-1 / 2, z$ \\
$\mathrm{~N}^{1}-\mathrm{H}^{1 \mathrm{C}} \cdots \mathrm{O}^{2}$ & 0.89 & 1.85 & $2.733(8)$ & 169.4 & \\
$\mathrm{~N}^{1}-\mathrm{H}^{1 \mathrm{~B}} \cdots \mathrm{O}^{1}$ & 0.89 & & \\
\hline
\end{tabular}

Table 4. Wavelengths $\left(\mathrm{cm}^{-1}\right)$ of IR absorption maxima in the spectra of starting amines and sulfates I-IV

\begin{tabular}{|c|c|c|c|c|c|c|c|}
\hline Compound & $v(\mathrm{NH}), v(\mathrm{CH})$ & $v\left(\mathrm{~N}^{+} \mathrm{H}\right)$ & $\begin{array}{l}\delta\left(\mathrm{HN}^{+} \mathrm{H}\right) \\
\delta\left(\mathrm{CN}^{+} \mathrm{H}\right)\end{array}$ & $v_{\text {as }}\left(\mathrm{SO}_{4}^{2-}\right)$ & $v_{\mathrm{s}}\left(\mathrm{SO}_{4}^{2-}\right)$ & $\delta_{\mathrm{as}}\left(\mathrm{SO}_{4}^{2-}\right)$ & $\delta_{\mathrm{s}}\left(\mathrm{SO}_{4}^{2-}\right)$ \\
\hline $\begin{array}{l}\mathrm{SO}_{4}^{2-} \text { free ion }\left(T_{\mathrm{d}}\right. \\
\text { symmetry) [15] } \\
\text { Benzylamine }\end{array}$ & $\begin{array}{l}3379 \mathrm{~s}, 3290 \mathrm{~s}, \\
3062 \mathrm{~s}, 3027 \mathrm{~s}, \\
2920 \mathrm{~s}, 2753 \mathrm{~m}\end{array}$ & & & $\begin{array}{c}1105 \\
v_{3}\left(F_{2}, \mathrm{IR},\right. \\
\text { Raman })\end{array}$ & $\begin{array}{c}983 \\
v_{1}\left(\mathrm{~A}_{1}\right. \\
\text { Raman })\end{array}$ & $\begin{array}{c}611 \\
v_{4}\left(F_{2}, \mathrm{IR},\right. \\
\text { Raman })\end{array}$ & $\begin{array}{c}450 \\
v_{2}(\mathrm{E}, \\
\text { Raman })\end{array}$ \\
\hline$\alpha$-Phenylethylamine & $\begin{array}{l}3465 \text { m.br, } 3178 \text { m, } \\
2997 \text { s, } 2887 \text { s } \\
\\
3367 \text { m, } 3286 \mathrm{~m}, \\
3084 \text { s, } 3027 \mathrm{~s}, \\
2962 \mathrm{~s}, 2967 \mathrm{~s}\end{array}$ & $\begin{array}{l}2676 \mathrm{~m} \\
2560 \mathrm{~m} \\
2341 \mathrm{~m} \\
2015 \mathrm{~m}\end{array}$ & $1635 \mathrm{~m}$ & $\begin{array}{l}1160 \text { sh, } 1118 \\
\text { v.s, } 1031 \mathrm{~m}\end{array}$ & $961 \mathrm{~m}$ & 619 s, $573 \mathrm{~m}$ & $\begin{array}{l}471 \mathrm{w}, \\
451 \mathrm{w}\end{array}$ \\
\hline II & $\begin{array}{l}3440 \mathrm{~m}, 3000 \text { s.br, } \\
2913 \text { s.br }\end{array}$ & $\begin{array}{l}2752 \mathrm{sh} \\
2668 \mathrm{~m} \\
2535 \mathrm{~m} \\
2151 \mathrm{~m}\end{array}$ & $\begin{array}{l}1635 \\
\text { sh, } \\
1614 \mathrm{~s}\end{array}$ & $\begin{array}{l}1134 \mathrm{sh}, 1122 \mathrm{v} . \mathrm{s}, \\
1090 \mathrm{~s}, 1061 \mathrm{~s}\end{array}$ & $971 \mathrm{~m}$ & $\begin{array}{l}635 \mathrm{sh}, 620 \mathrm{~m}, \\
588 \mathrm{~m}\end{array}$ & $\begin{array}{l}465 \quad w, \\
430 w\end{array}$ \\
\hline $\begin{array}{l}N, N- \\
\text { Dimethylbenzylamin } \\
\mathrm{e}\end{array}$ & $\begin{array}{l}3027 \mathrm{~s}, 2893 \mathrm{~s} \\
2846 \mathrm{~s}, 2804 \mathrm{~s}\end{array}$ & & & & & & \\
\hline III & $\begin{array}{l}3406 \text { s.br, } \\
3038 \text { m.br }\end{array}$ & $\begin{array}{l}2704 \mathrm{~m} . \mathrm{br} \\
2405 \mathrm{~m} . \mathrm{br} \\
2265 \mathrm{~m}\end{array}$ & $1649 \mathrm{~m}$ & $\begin{array}{lrr}1140 & \text { sh, } & 1090 \\
\text { v.s, } & 1058 & \text { v.s, } \\
1047 & \text { v.s } & \end{array}$ & $961 \mathrm{~m}$ & $709 \mathrm{~m}, 605 \mathrm{w}$ & $\begin{array}{l}494 \mathrm{w}, \\
415 \mathrm{~m}\end{array}$ \\
\hline Dibenzylamine & $\begin{array}{l}3313 \mathrm{~m}, 3105 \mathrm{~m} \\
3027 \mathrm{~s}, 2918 \mathrm{~s} \\
2816 \mathrm{~s}\end{array}$ & & & & & & \\
\hline IV & $\begin{array}{l}3460 \mathrm{~m}, 3061 \mathrm{sh}, \\
3290 \mathrm{sh}, 3000 \mathrm{v} . \mathrm{s}, \\
2833 \mathrm{~m}\end{array}$ & $\begin{array}{l}2641 \mathrm{~m} \\
2474 \mathrm{~m} \\
2364 \mathrm{~m} \\
2341 \mathrm{~m}\end{array}$ & $\begin{array}{l}1623 \mathrm{~m} \\
1615 \mathrm{~m}\end{array}$ & 1134 s.br & $920 \mathrm{~m}$ & $\begin{array}{l}668 \mathrm{~m}, 658 \mathrm{sh}, \\
645 \mathrm{~m}\end{array}$ & $\begin{array}{l}513 \mathrm{sh}, \\
415 \mathrm{w}\end{array}$ \\
\hline
\end{tabular}

Two components of thrice degenerate bending bands $\delta_{\text {as }}\left(\mathrm{SO}_{4}^{2-}\right)\left(v_{4}\right)$ in IR spectrum of compound I were observed as strong $\left(619 \mathrm{~cm}^{-1}\right)$ and moderate intensity $\left(573 \mathrm{~cm}^{-1}\right)$ bands. In the Raman spectra, two moderate intensity bands at 623 and $590 \mathrm{~cm}^{-1}$ corresponded to those IR bands, thus pointing at the $v_{4}\left(F_{1}>A_{2}+E_{U}\right)$ splitting.

In the range of twice degenerate deformation vibration $v_{2}\left(450 \mathrm{~cm}^{-1}\right)$ of free $\mathrm{SO}_{4}^{2-}$ ion, in IR spec- 
trum of sulfate $\mathbf{I}$ the appearance of two well defined shoulders (471 and $451 \mathrm{~cm}^{-1}$ ) of the out-of-plane $\delta(\mathrm{CCH})$ bending at $485 \mathrm{~cm}^{-1}$ is notable. In the Raman spectrum, $\delta_{\mathrm{s}}\left(\mathrm{SO}_{4}^{2-}\right)$ vibrations were assigned to the weak band at $446 \mathrm{~cm}^{-1}$.

Bands of stretching and bending vibrations of $\mathrm{SO}_{4}^{2-}$ anion in IR spectra of sulfates II-IV were assigned by comparative analysis of spectra of the salts, of the initial benzylamines, and of compound $\mathbf{I}$. It follows from Table 3 that the intrinsic vibrations of $\mathrm{SO}_{4}^{2-}$ ion appeared in IR spectra as the full set of possible frequencies due to splitting of the $\mathrm{F}_{2}$ and $\mathrm{E}$ vibrations and activity of the $A_{1}$ vibrations; that could point at a low symmetry of the anion in the crystalline salts as compared with $T_{\mathrm{d}}$ symmetry of the free anion.

In IR spectra of the salts the range of 3500$2000 \mathrm{~cm}^{-1}$ contained complex bands of $\mathrm{N}-\mathrm{H}$ stretching vibrations of the $\mathrm{NH}_{3}^{+}, \mathrm{NH}_{2}^{+}$, and $\mathrm{NH}^{+}$groups $[15,16]$. Noteworthily, the bands at $2015 \mathrm{~cm}^{-1}$ (I), $2151 \mathrm{~cm}^{-1}$ (II), $2265 \mathrm{~cm}^{-1}$ (III), and $2341 \mathrm{~cm}^{-1}$ (IV) were due to strong hydrogen bonds $\mathrm{NH} \cdots \mathrm{O}$ in the crystalline salts; the presence and position of those bands in the IR spectra could characterize the participation of benzylammonium cations in the hydrogen bonding [17].

The characteristic scissor vibration bands of ammonium groups, $\delta\left(\mathrm{HN}^{+} \mathrm{H}\right)$ and $\delta\left(\mathrm{NN}^{+} \mathrm{H}\right)$, were detected in the relatively narrow region of $1650-1610 \mathrm{~cm}^{-1}$.

In the thermogram of sulfate $\mathbf{I}$, two endothermic effects were detected at $210-320^{\circ} \mathrm{C}\left(T_{\max } 280^{\circ} \mathrm{C}, \Delta m\right.$ $69.86 \%)$ and $390-550^{\circ} \mathrm{C}\left(T_{\max } 460^{\circ} \mathrm{C}, \Delta m 7.94 \%\right)$ as well as an exothermic effect at $550-660^{\circ} \mathrm{C}\left(T_{\max } 600^{\circ} \mathrm{C}\right.$, $\Delta m 7.94 \%$ ). In the thermogram of compound II the endothermic effect at $240-370^{\circ} \mathrm{C}\left(T_{\max } 300^{\circ} \mathrm{C}, \Delta m\right.$ $64.29 \%$ ) was detected along with the exothermic effect at $390-660^{\circ} \mathrm{C}\left(T_{\max } 600^{\circ} \mathrm{C}, \Delta m 17.03 \%\right)$. When in air, compounds I and II were stable, the decomposition onset being detected at 210 and $240^{\circ} \mathrm{C}$, respectively; the $(S)$ enantiomer II started decomposing at $230^{\circ} \mathrm{C}$ [3]. Noteworthily, the low-temperature effects in thermograms of compounds I and II corresponded to elimination of the same fragments $(M \approx 218 \mathrm{~g} / \mathrm{mol})$, evidently showing the special feature of thermolysis of benzylammonium sulfates.

The thermogram of compound III contained three endothermic effects at $90-140^{\circ} \mathrm{C}\left(T_{\max } 100^{\circ} \mathrm{C}, \Delta m\right.$ $16.22 \%), 140-250^{\circ} \mathrm{C}\left(T_{\max } 170^{\circ} \mathrm{C}, \Delta m 18.24 \%\right)$, and $300-385^{\circ} \mathrm{C}\left(T_{\max } 350^{\circ} \mathrm{C}, \Delta m 46.62 \%\right)$ as well as an exothermic effect at $400-590^{\circ} \mathrm{C}\left(T_{\max }=550^{\circ} \mathrm{C}, \Delta m=\right.$ $4.05 \%)$. The thermogram of compound IV contained an endothermic effect at $90-150^{\circ} \mathrm{C}\left(T_{\max } 130^{\circ} \mathrm{C}, \Delta m\right.$ $11.92 \%)$ along with two exothermic effects at 230 $360^{\circ} \mathrm{C}\left(T_{\max } 290^{\circ} \mathrm{C}, \Delta m 70.86 \%\right)$ and $530-610^{\circ} \mathrm{C}\left(T_{\max }\right.$ $\left.580^{\circ} \mathrm{C}, \Delta m 2.65 \%\right)$.

To conclude, this work demonstrated new examples of stabilization of sulfate anion in the form of alkylammonium salts prepared in the $\mathrm{SO}_{2}-\mathrm{L}-\mathrm{H}_{2} \mathrm{O}$ systems (L were mixed amines) in the presence of air according to the formal scheme.

$$
2 \mathrm{SO}_{2}+4 \mathrm{R}_{n} \mathrm{NH}_{3-n}+2 \mathrm{H}_{2} \mathrm{O}+\mathrm{O}_{2} \rightarrow 2\left(\mathrm{R}_{n} \mathrm{NH}_{4-n}\right)_{2} \mathrm{SO}_{4} .
$$

The effect was reported for the first time in [18].

The possibility of mild oxidation of $\mathrm{SO}_{2}$ under the specified conditions will be further studied in detail involving other amine ligands.

\section{EXPERIMENTAL}

Technical grade sulfur(IV) oxide was used after purification and drying [21]. All amines were of pure grade and were used as received.

Analysis for carbon, hydrogen, and nitrogen content was performed using a CHN elemental analyzer; content of sulfur was determined using the Scheniger method [19].

Raman spectra were obtained using a DFS-24 spectrometer with excitation at 532 and $632.8 \mathrm{~nm}$ (neodymium and helium-neon lasers, respectively).

IR spectra were recorded using a spectrophotometer Spectrum BX II FT-IR System (Perkin-Elmer) (KBr); mass spectra were registered on a MKh-1321 instrument (direct amission of the sample into the ion source, ionizing electrons energy $70 \mathrm{eV}$ ).

Thermal stability of the compounds was determined by the differential thermal analysis (the Q-1500 D Paulik-Paulik-Erdey derivatograph, platinum crucible, in air, $20-1000^{\circ} \mathrm{C}$ at a rate $10 \mathrm{deg} / \mathrm{min}$, sensitivity $1 / 5$ of the maximum one, $\mathrm{Al}_{2} \mathrm{O}_{3}$ reference).

$\mathrm{X}$-ray diffraction studies were performed using the Oxford Diffraction diffractometer ( $\mathrm{Mo} K_{\alpha}$ radiation, graphite monochromator, CCD detector Sapphire-3). The structures were solved and refined using SHELX97 software package [20]. Hydrogen atoms positions were found via differential analysis of electron density and refined in the rider model. The basic crystallographic parameters of compound II were as follows: $\mathrm{C}_{16} \mathrm{H}_{24} \mathrm{~N}_{2} \mathrm{O}_{4} \mathrm{~S}$, monoclinic, $M 340.43$, space group $C 2$, a 10.876(2), b 6.0814(10), c 13.609(4) $\AA$; $\beta$ 92.47(3),$V$ 899.3(4) $\AA^{3}$ at $T$ 293(2) K, Z 2, $d_{\text {calc }}$ 
$1.257 \mathrm{~g} / \mathrm{cm}^{3}, F_{000} 364$, crystal $0.30 \times 0.20 \times 0.02 \mathrm{~mm}$, $\mu \quad 0.200 \mathrm{~mm}^{-1}\left[\lambda\left(\mathrm{Mo} K_{\alpha}\right) \quad 0.71073 \AA\right]$, transmission coefficients $T_{\min } / T_{\max } 0.9424 / 0.9960 ;-6 \leq h \leq 13,-7 \leq$ $k \leq 7,-15 \leq l \leq 16, \omega$-scan at $3.00 \leq \theta \leq 25.48^{\circ}, 2410$ measured reflections, 1479 independent reflections $\left(R_{\text {int }} 0.0969\right), 986$ reflections with $I_{h k l}>2 \sigma(I)$, coverage completeness $94.0 \%$; final parameters of full-matrix refinement of 108 parameters according to $F^{2}$ using the 986 reflections: $R_{\mathrm{F}} 0.0923, w R^{2} 0.2041\left(R_{\mathrm{F}} 0.1269\right.$, $w R^{2} 0.2286$ for all independent reflections), $S$ 1.003, $\Delta \rho_{\min } / \Delta \rho_{\max }-0.253 / 0.387 e / \AA^{3}$.

Benzylammonium sulfate (I). Gaseous $\mathrm{SO}_{2}$ was passed through a mixture of $10 \mathrm{~mL}$ of benzylamine and $20 \mathrm{~mL}$ of water $\left(0^{\circ} \mathrm{C}\right)$ at $50 \mathrm{~mL} / \mathrm{min}$ till $\mathrm{pH}$ dropped below 1.0. Then the reaction mixture was isothermally evaporated at room temperature to full dehydration. The so formed solid product was washed with benzene and recrystallized from water. Yield $14.30 \mathrm{~g}(82.3 \%)$, white crystals with specific smell, $\mathrm{mp}$ $105-107^{\circ} \mathrm{C}$. Mass spectrum, $m / z\left(I_{\text {rel }}, \%\right)$ : 107 (69) $\left[M_{\mathrm{L}}\right]^{+} ; 106(100)\left[M_{\mathrm{L}}-\mathrm{H}\right]^{+} ; 91(13)\left[\mathrm{C}_{7} \mathrm{H}_{7}\right]^{+} ; 78(15) ;$ $77(22)\left[\mathrm{C}_{6} \mathrm{H}_{5}\right]^{+} ; 52(8) ; 51$ (15); 39 (7). Found, \%: C 53.49; $\mathrm{H} 6.24 ; \mathrm{N} 8.64 ; \mathrm{S} 9.84 . \mathrm{C}_{14} \mathrm{H}_{20} \mathrm{~N}_{2} \mathrm{O}_{4} \mathrm{~S}$. Calculated, \%: C 53.83; H 6.45; N 8.97; S 10.26. M312.38.

a-Phenylethylammonium sulfate (II) was prepared similarly from $10 \mathrm{~mL}$ of phenylethylamine and $50 \mathrm{~mL}$ of water. Yield $13.37 \mathrm{~g}(89.1 \%)$, white crystals (without further purification), mp $195-200^{\circ} \mathrm{C}$. Mass spectrum, $m / z\left(I_{\text {rel }}, \%\right): 120(8)\left[M_{\mathrm{L}}-\mathrm{H}\right]^{+} ; 107$ (8); $106(100)\left[M_{\mathrm{L}}-\mathrm{CH}_{3}\right]^{+} ; 79$ (24); 77 (13) $\left[\mathrm{C}_{6} \mathrm{H}_{5}\right]^{+}$; 53 (9), 51 (10); 44 (18); 43 (7); 42 (13). Found, \%: C $56.89 ; \mathrm{H} 7.39 ; \mathrm{N} 8.51 ; \mathrm{S}$ 9.77. $\mathrm{C}_{16} \mathrm{H}_{24} \mathrm{~N}_{2} \mathrm{O}_{4} \mathrm{~S}$. Calculated, \%: C 56.45; H 7.11; N 8.23; S 9.42. M 340.44.

$\mathrm{N}, \mathrm{N}$-Dimethylbenzylammonium sulfate (III) was prepared similarly from $10 \mathrm{~mL}$ of $N, N$-dimethylbenzylamine and $50 \mathrm{~mL}$ of water. Yield $10.51 \mathrm{~g}$ $(92.8 \%)$, yellow oily liquid. Mass spectrum, $\mathrm{m} / \mathrm{z}\left(I_{\text {rel }}\right.$, \%): $135(40)\left[M_{\mathrm{L}}\right]^{+} ; 134(30)\left[M_{\mathrm{L}}-\mathrm{H}\right]^{+} ; 92(5) ; 91(40)$ $\left[\mathrm{C}_{7} \mathrm{H}_{7}\right]^{+} ; 65$ (13\%); 58 (100); 44 (10); 42 (17). Found, \%: C 59.13; H 7.41; N 7.39; $\mathrm{S} 9.05 . \mathrm{C}_{18} \mathrm{H}_{28} \mathrm{~N}_{2} \mathrm{O}_{4} \mathrm{~S}$. Calculated, \%: C 58.67; H 7.66; N 7.60; S 8.70. M 368.49.

Dibenzylammonium sulfate (IV) was prepared similarly from $10 \mathrm{~mL}$ of dibenzylamine and $50 \mathrm{~mL}$ of water. Yield $8.07 \mathrm{~g}(91.4 \%)$, white crystals, $\mathrm{mp} 93^{\circ} \mathrm{C}$. Mass spectrum, $m / z\left(I_{\text {rel }}, \%\right): 198(14)\left[M_{\mathrm{L}}+\mathrm{H}\right]^{+} ; 196$ (14) $\left[M_{\mathrm{L}}-\mathrm{H}\right]^{+} ; 120$ (10); 106 (85); 105 (26); 92 (26); $91(100)\left[\mathrm{C}_{7} \mathrm{H}_{7}\right]^{+} ; 77(31 \%)\left[\mathrm{C}_{6} \mathrm{H}_{5}\right]^{+} ; 65(14) ; 64(17)$ $\left[\mathrm{SO}_{2}\right]^{+} ; 51$ (14). Found, \%: C 67.73; H 6.81; N 8.61; S 6.35. $\mathrm{C}_{28} \mathrm{H}_{32} \mathrm{~N}_{2} \mathrm{O}_{4} \mathrm{~S}$. Calculated, \%: C 68.27; H 6.55; N 5.69; S 6.51. M 492.63.

\section{REFERENCES}

1. Rademeyer, M., Acta Cryst. (E), 2003, vol. 59, no. 11, p. 01860 .

2. Amini, M.M., Nasiri, S., and Ng, S.W., Acta Cryst. (E), 2007, vol. 63, no. 3, p. o1361.

3. Aakeroy, C.B., Hitchcock, P.B., Moyle, B.D., and Seddon, K.R., J. Chem. Soc. Chem. Commun., 1989, vol. 23, p. o1856.

4. Lee, C. and Harrison, W.T.A., Acta Cryst. (E), 2003, vol. 59, no. 12, pp. m1151-m1153.

5. Cihelka, J., Havliček, D., Gyepes, R., Němec, I., and Kolev, Z., J. Mol. Str., 2010, vol. 980, nos. 1-3, p. 31.

6. Gel'mbol'dt, V.O., Gavrilova, L.A., Koroeva, L.V., and Ennan, A.A., Vopr. Khim. Khim. Tekhol., 2008, no. 2, p. 153.

7. Gel'mbol'dt, V.O., Gavrilova, L.A., and Ennan, A.A., Vopr. Khim. Khim. Tekhol., 2004, no. 4, p. 33.

8. Hernandez Linares, M.-G., Guerrero Luna, G., and Bernes, S., Acta Cryst. (E), 2010, vol. 66, no. 5, p. o1118.

9. Kinbara, K., Hashimoto, Y., Sukegawa, M., Nohira, H., and Saigo, K., J. Am. Chem. Soc., 1996, vol. 118, no. 14, p. 3441.

10. Kinbara, K., Kai, A., Maekawa, Y., Hashimoto, Y., Naruse, S., Hasegawa, M., and Saigo, K., J. Chem. Soc. Perkin Trans. 2, 1996, no. 2, p. 247.

11. Parshad, H., Frydenvang, K., Liljefors, T., Sorensen, H.O., and Larsen, C., Int. J. Pharm., 2004, vol. 9, no. 269(1), p. 157.

12. Armstrong, W.W., Moppett, C.E., and Windisch, W.W., USA Patent no. 4331599, 1982.

13. Higashide, E. and Jono, K., Patent EP0175338 A2, 1986.

14. Vul'fson, N.S., Zaikin, V.G., and Mikaya, A.I., Massspektrometriya organicheskikh soedinenii (Mass-Spectrometry of Organic Compounds), Moscow: Khimiya, 1986, p. 285.

15. Nakamoto, K., Infrared and Raman Spectra of Inorganic and Coordination Compounds, Willey, 1997.

16. Structure Determination of Organic Compounds: Tables of Spectral Data, Pretsch, E., Bühlmann, P., and Affolter, C., Eds., Springer, 2000.

17. Guerfel, T., Bdiri, M., and Jouini, A., J. Chem. Cryst., 2000, vol. 30, no. 12, p. 799.

18. Khoma, R.E., Ennan, A.A., Shishkin, O.V., Baumer, V.N., and Gel'mbol'dt, V.O., Russ. J. Inorg. Chem., 2012, vol. 57, no. 12, p. 1559.

19. Klimova, V.A., Osnovnye metody analiza organicheskikh soedinenii (Basic Methods of Analysis of Organic Compounds), Moscow: Khimiya, 1975.

20. Sheldrick, G.M., Acta Cryst. (A), 2008, vol. 64, no. 1, p. 112.

21. Gordon, A.J. and Ford, R.A., The Chemist's Companion. A Handbook of Practical Data, Techniques and References, New York: Wiley, 1972. 